\title{
trabalhonecessário
}

issn: $1808-799 \mathrm{X}$

\author{
ano 8 - número 10 - 2010
}

\section{CONVERSÃO DA DÍVIDA PÚBLICA POR EDUCAÇÃO BÁSICA: É PARA DEMOCRATIZAR OU PARA MERCANTILIZAR?}

\author{
Thaís Rabello de Souza ${ }^{1}$ - thaisrabello@hotmail.com
}

\section{INTRODUÇÃO}

Este artigo socializa parte da pesquisa cujo título é "(Con)formando professores eficazes: a relação política entre o Brasil e a Organização para Cooperação e Desenvolvimento Econômico (OCDE)", e tem por objetivo tratar da mercantilização da educação, em especial, da educação superior voltada para a formação de professores da educação básica. O objetivo do estudo foi entender o fenômeno da interferência dos organismos internacionais, em especial, do Banco Mundial, da Unesco e da OCDE que, juntos ao Instituto Nacional de Estudos e Pesquisas Educacionais (INEP), organizam acordos de cooperação técnica por intermédio do Programa de Indicadores Mundiais da Educação (WEI). A OCDE em parceria com a Unesco e a Comissão Européia tem como objetivo organizar uma rede mundial de Avaliação Externa dos sistemas de ensino e validação das competências (Maués, 2003; Ramos, 2002) para os futuros trabalhadores da nova sociedade do conhecimento (Drucker, 1993). Tal projeto já chegou ao chão das escolas brasileiras.

O País não é membro da OCDE, criada na década de 1960, no âmbito do Plano Marshall, sob forte intervenção dos Estados Unidos, mas mantêm relações diretas com tal organismo desde 1997. Delimitamo-nos a refletir sobre a Práxis do Governo e da OCDE enquanto esferas representativas do capital, as quais se utilizam de Práxis oriundas do neoliberalismo da Terceira Via. Então, como metodologia de investigação trabalhamos com análise documental para sintetizar as informações e entender a concretude das propostas apresentadas. Como ferramentas epistemológicas, adotamos as categorias do 


\section{trabalhonecessário}

issn: $1808-799 \mathrm{X}$

ano 8 - número 10 - 2010

materialismo histórico - a Práxis, a Totalidade, a Particularidade, a Contradição e a Mediação - construído pela obra de Marx.

Buscamos analisar as estratégias de "contra-reforma" (Lima, 2007) da OCDE, dos organismos internacionais e do Governo Lula. O termo contrarreforma foi utilizado para definir suas Práxis, referentes aos acordos de democratização da educação básica e da superior, os quais, na verdade, vislumbram diretamente a mercantilização. A conversão da dívida pública por educação básica não indica, em nossa opinião, a ampliação dos direitos da classe trabalhadora, mas apenas estratégias de conciliação entre classes para manter a hegemonia burguesa e a subordinação do trabalho ao capital.

\section{A PRÁXIS DA OCDE}

A Organização de Cooperação e Desenvolvimento Econômico (OCDE ou OECD) reúne 30 países membros num fórum único para, segundo ela, discutir, desenvolver e aprimorar políticas econômicas e sociais. Seus membros, atualmente, são: Alemanha, Austrália, Áustria, Bélgica, Canadá, Coréia do Sul, Dinamarca, Eslováquia, Espanha, Estados Unidos, Finlândia, França, Grécia, Holanda, Hungria, Irlanda, Islândia, Itália, Japão, Luxemburgo, México, Noruega, Nova Zelândia, Polônia, Portugal, Reino Unido, República Tcheca, Suécia, Suíça e Turquia. O Brasil não faz parte da OCDE, atua como membro colaborador, com destaque para a área da educação cujo trabalho é mediado pelo INEP.

Atualmente (2008-2009), o Secretariado Técnico chefiado pelo Secretário-Geral da OCDE, Angel Gurría. No Brasil, o Secretário Geral para a subdivisão da América Latina é o economista Luiz de Mello, PHD pela Universidade de Kent, no Reino Unido, e ex membro do Fundo Monetário Internacional (FMI). 


\section{trabalhonecessário}

issn: 1808-799X

ano 8 - número 10 - 2010

A OCDE propõe-se a ofertar assessoria técnica aos governos para o desenvolvimento de políticas domésticas e internacionais acerca de governança corporativa, da economia da informação e dos desafios de uma população que está envelhecendo. Sua base política é de origem social liberal, mantendo premissas básicas do neoliberalismo como, por exemplo, a redução dos direitos trabalhistas por meio da flexibilização do trabalho, e, ao mesmo tempo, incorporando demandas da sociedade civil, como ampliação do acesso à educação, de modo a garantir um discurso hegemônico que visa à coesão social com base no neoliberalismo da Terceira Via (LIMA, 2007).

Junto à Comissão Europeia, que é formada pelo empresariado europeu, esse organismo interfere na formação da classe trabalhadora desde a década de 1980. Segundo Maués (2003), a OCDE, há tempos, procura atender as demandas da Mesa Redonda dos Industriais Europeus, criada em 1983, em termos de regulação da educação; marco que a autora denominou como obsessão pelas competências, momento em que as propostas de reforma na educação profissional ganharam força na Europa. Segundo Shiroma, Moraes e Evangelista (2004), na década seguinte (1990), os organismos internacionais criaram seus departamentos e secretarias de educação para corporificar tal projeto, montando um pacote de reformas a serem implantadas por intermédio dos ministérios da educação de cada país, prioritariamente. As agendas deveriam ser desenvolvidas para obtenção do consenso, com vocábulos semelhantes, numa comunhão conceitual que ressignificasse, nos parâmetros do social-liberalismo, boa parte das demandas sociais da classe trabalhadora. Os pontos da agenda internacional foram: o desenvolvimento humano tomado por políticas de contenção à pobreza; a formação contínua ou educação ao longo da vida garantindo a reprodução do capital, especialmente através da educação à distância (EaD); tecnologias da informação e comunicação (TICs) para justificar o desemprego; a democracia significando liberdade de acordos entre diferentes esferas do poder e frações burguesas, de modo que os termos cidadania e sociedade civil fossem, também, ressignificados a partir da economia corporativa; e, por fim, a avaliação dos sistemas de ensino como a 


\section{trabahonecessário}

issn: $1808-799 \mathrm{X}$

ano 8 - número 10 - 2010

nova estratégia de gestão. Atrelou-se a avaliação ao financiamento e, estes, aos parâmetros produtividade na lógica das competências.

No Brasil, a OCDE dirige o Sistema de Indicadores Educacionais da OCDE (INES), que abrange informações e orientações sobre financiamento, resultados, desempenho educacional para o mercado de trabalho, que, por sua vez, são repassadas para o Programa WEI, desdobrando-se em conclusões estatísticas de publicações da OCDE, tais como o: Programa Internacional de Avaliação de Alunos (PISA); o Education at a Glance ou Panorama da Educação, o MERCOSUL Educacional e a Pesquisa TALIS, realizada entre os anos de 2008 e 2009 com professores e diretores da educação básica em 400 escolas brasileiras.

Ressaltamos que o processo de cooperação entre Brasil, OCDE, Unesco e Banco Mundial foi consolidado em 1997 visando especificamente implantar políticas voltadas para professores da educação básica, organizados por intermédio do WEI e INES. Os gestores educacionais, as Secretarias e Fundações de todo o país têm acesso aos dados e orientações da OCDE por intermédio do MEC/INEP, e um dos principais exemplos são as políticas de Avaliação Externa de desempenho dos estudantes.

Um dos primeiros exemplos da utilização dos dados da educação brasileira, repassados para o WEI foi o documento "Docentes para las escuelas del manãna" (Unesco, 2001), do qual o Brasil, o Chile e a Argentina participaram. Nele foram apresentas análises dos indicadores educativos mundiais e, a ação, dos professores, foi focada como fator decisivo para manter a qualidade na educação, cujo parâmetro são os países da OCDE. Supomos que a OCDE procura legitimar o investimento em educação básica para apoiar os Estados no desinvestimento à educação superior nas universidades públicas, abrindo campo para o empresariado em geral. De acordo com relatório de Célio da Cunha e Marcelo Souto, publicado pela Unesco com apoio do BM e do FMI, referentes à II Reunião do Comitê Social da Conversão da Dívida por Educação Básica, o objetivo foi encontrar estratégias para mobilização de 


\section{trabahonecessário}

issn: $1808-799 \mathrm{X}$

ano 8 - número 10 - 2010

recursos para a educação. Vejamos: "além da OCDE, BIRD e BID destinaram aproximadamente US\$ 670 milhões em educação na América Latina em 2002. No total, a região recebeu US\$1,2 bilhão de cooperação internacional em educação" (Unesco, 2005), e, o Brasil, foi "o sexto principal destino da ajuda internacional da OCDE na região, recebendo US\$ 376 milhões" (idem) entre os anos de 2001 e 2002. Supomos que essa ajuda financeira tenha como moeda de troca a proposta de redução da dívida externa de países como o Brasil, sob a regulação do $\mathrm{BM}$, que defende o enxugamento de recursos para a educação superior. Acreditamos que, por outro lado, os organismos, como representantes do capital, vislumbrem a expansão dos seus negócios na área da educação superior, através da formação docente em serviço por intermédio da EaD (BM, 2003). Ressaltamos que o BM é responsável por cobrar os empréstimos da OCDE e esta, por avaliar os riscos e as possibilidades de investimentos para o setor privado de acordo com o documento traduzido com o título "Metodologia para a avaliação de sistemas nacionais de aquisição de bens e serviços" (OCDE, 2006a). Segundo Souto e Cunha, "a conversão da dívida pública brasileira representa uma oportunidade de aumento dos investimentos em educação [...] alternativas que contemplem a conversão da dívida pública mobiliária, assim como a dívida privada [...] requerem grande coordenação dentro do governo e com o mercado financeiro" (Cunha \& Souto, 2005, apud Unesco, 2005, p. 19).

Por fim, ressaltamos que no ano de 2007, a OCDE publicou o documento, cujo título, traduzido, recebeu o nome de "A educação superior e as regiões: globalmente competitivas, localmente comprometidas", propondo um ajuste nos processos de reformas realizadas na América latina, de modo a contemplar empresários da educação e da indústria. Em 2009, esse organismo publicou outro documento traduzido com o título de "O ensino superior na sociedade do conhecimento", onde deixou clara a proposta de mercantilização da educação superior através da sua internacionalização; cujo respaldo discursivo foi a THC e a preparação de mão de obra para a sociedade do 


\section{trabalhonecessário}

issn: 1808-799X

ano 8 - número 10 - 2010

conhecimento (Drucker, 1993) como meio de obtenção do desenvolvimento econômico numa sociedade que supostamente superou a luta de classes.

Vários organismos, em especial a OCDE em parceria com a Comissão Européia procuram regulamentar e promover a consolidação das metas do Acordo de Bolonha, na busca da expansão do ensino superior com base no modelo europeu, produzindo documentos e avaliações sobre os sistemas de ensino, de modo a incentivar a internacionalização da educação superior (SIQUEIRA, 2005), buscando alimentar a expansão da educação como serviço a ser comercializado pelos empresários estrangeiros e nacionais. Supomos que a OCDE esteja interessada expandir o mercado educacional no Brasil.

\section{O NEOLIBERALISMO DA TERCEIRA VIA COMO PRÁXIS DA OCDE E DO GOVERNO LULA}

Segundo Acácia Kuenzer (1998), a categoria Práxis é aquela que viabiliza um conhecimento novo sobre o objeto que é produzido quando superamos a sua dimensão fenomênica e aparente para encontrar sua concretude, ou seja, destruindo a sua pseudoconcreticidade (Kosik, 1976) através do pensamento dialético crítico (que difere a representação e 0 conceito da coisa em si), o qual rejeita as representações ou categorias do senso comum tomadas como conceitos e verdades satisfazendo à Práxis utilitária do ser humano. Somente o uso desse senso comum não viabiliza a compreensão das coisas e da realidade como um todo articulado dentro do movimento da história humana. Nesse sentido, a busca por uma apreensão do real baseada na teoria (como representação da realidade) que se expressa na literatura marxiana nos foi fundamental para transformar o empírico apenas num marco inicial da análise, transformando sua relação, sua manifestação como fenômeno, em objeto de investigação inteligível e apreensível (Kuenzer, 2000, p.64). O fenômeno da cooperação técnica entre o Brasil e a OCDE traz, 


\section{trabalhonecessário}

issn: $1808-799 \mathrm{X}$

ano 8 - número 10 - 2010

na sua essência, uma relação política, a qual consideramos, que, de ambas as partes, ancora-se no neoliberalismo da Terceira Via.

Para Lima (2007, p.60) a defesa do Estado de bem-estar social foi a pauta principal do socialismo reformista e deste fato histórico resultou uma nova tentativa de salvação do capitalismo das crises cíclicas, como nova forma de organizar o projeto hegemônico burguês. O novo projeto neoliberal chamado de Terceira Via busca construir uma ideologização maciça sobre a possibilidade de humanização do capitalismo, ou sua reforma. Segundo Lima (2007, p.58-59), "este projeto foi apresentado por Giddens ${ }^{2}$ como:

[...] uma filosofia política sintonizada com as mudanças que estão ocorrendo no quadro mundial, um programa de "modernização" da economia, do sistema político e do sistema de bem estar social. Este projeto pode ser identificado como social-liberalismo, na medida em que, de um lado, mantém as premissas básicas do liberalismo, e de outro, recupera elementos centrais do reformismo social-democrata, apresentando-se inclusive como uma nova social-democracia modernizadora. [...] A Terceira Via apresenta seu arcabouço teórico desvinculado do pensamento socialista, muito embora advogue para si a identificação política como de esquerda. Inspirado nas análises de Norberto Bobbio, o principal articulador político da Terceira Via considera que "ser de esquerda é estar preocupado com a redução da desigualdade - definindo de forma mais positiva, com a busca de justiça social. Outros valores de esquerda como a cooperação social e proteção aos fracos, originam-se desta eterna preocupação. (Giddens, 2001, p.46, apud Lima, op.cit).

Lima (2007, p.60-61) afirma que a Terceira Via é um projeto neoliberal porque realiza quatro movimentos adequados ao liberalismo: 1) Desloca o homem da história, abstraindo-o da sua condição de possível produtor e reprodutor das condições materiais da sua existência; o objetivo é particularizar os sujeitos, individualizá-los, eliminando a perspectiva de que suas ações se configurem em Práxis coletivas, na ótica da luta de classes. 2) Naturaliza o capitalismo como algo não concebido pela história, mas como uma sucessão de fatos inevitáveis que não permitem a construção de outro projeto societário; naturaliza a impossibilidade do socialismo e propõe a humanização ou reforma 


\section{trabahonecessário}

issn: $1808-799 \mathrm{X}$

ano 8 - número 10 - 2010

do capitalismo como a única alternativa possível. 3) Reitera o fim do socialismo e a impossibilidade de transição para outro projeto de sociabilidade dada a crise do socialismo; "Esta análise confunde propositalmente o fim do socialismo real com o fim da divisão entre classes posta pelo capitalismo" (Lima, 2007, p.61). 4) Recupera pontos centrais da crítica neoliberal ao Estado de bem-estar social: as limitações fiscais para o financiamento, a suposta passividade dos indivíduos e a tendência à burocratização.

Na ótica de Lima (2007), dentre as críticas da Terceira Via, direcionadas ao neoliberalismo, está a de que a lógica neoliberal defende o sistema de mercado; enfatiza o individualismo econômico com vistas à democracia e trata as transformações geradas pela globalização de forma limita-nos às necessidades de desregulamentação dos mercados e maximização dos lucros. O problema, na ótica da Terceira Via, estaria em que o neoliberalismo não percebe a "importância do capital social, ou seja, a ação social voluntária dos indivíduos e grupos, e da solidariedade e responsabilidade social dos empresários" (idem, p.61). A Terceira Via defende que haja um reordenamento da vida coletiva e individual articulando a solidariedade social. Contudo, procura recuperar, da mesma forma que o neoliberalismo, o individualismo como pressuposto básico da sua construção analítica, mantendo o valor moral radical do liberalismo burguês. O novo individualismo, reformulado na ótica da Terceira Via de Giddens (1999), segundo Lima (2007), ao invés de ser uma expressão do comportamento interesseiro e tendente à maximização dos lucros como na ótica neoliberal, estimularia, contraditoriamente, os indivíduos a participar em conjunto das atividades pautadas na solidariedade social (Lima, 2007, p.61). Nesse contexto "A liberdade individual, as noções de responsabilidade social e solidariedade expressam uma concepção do indivíduo deslocado da luta de classes" (idem); sendo que o discurso da nova social-democracia reafirma que há valores universais sobre a vida humana, os chamados direitos humanos universais e assim por diante, responsabilizando os indivíduos na condução desse projeto societário. 


\title{
trabahonecessário
}

issn: 1808-799X

ano 8 - número 10 - 2010

\begin{abstract}
Essa responsabilidade individual vincula-se ao conceito durkheimiano de solidariedade social e, na medida em que reduz os antagonismos de classe às incapacidades de indivíduos ou de grupos sociais, a luta de classes perde a centralidade e é substituída pela tentativa de conciliação dos interesses entre capital e trabalho. (Lima, 2007, p.62)
\end{abstract}

A pobreza e o desemprego são considerados consequências dessa incapacidade dos indivíduos em utilizarem suas habilidades e competências, assim, os grupos e indivíduos menos capacitados podem necessitar, por um tempo, de ajuda de outros para promover a justiça social. Segundo Lima, "a noção de justiça social, segundo o pensamento giddeniano, não pode estar desvinculada dos deveres individuais e do apoio mútuo entre indivíduos e grupos sociais, e está fundamentada na concepção de igualdade de oportunidades" (Giddens, 1999, apud Lima, 2007, p.62).

Além do individualismo, como valor moral, ser retomado pela Terceira Via, um segundo elemento central também foi incorporado do pensamento liberal: o mercado foi e é considerado como lócus da eficácia econômica, por onde o capital privado cria riqueza e realiza investimento social por meio de uma economia mista, onde as fronteiras entre o público e o privado são diluídas (idem). Contudo, para a Terceira Via o mercado não pode se autoregular. Faz-se necessária a intervenção do Estado como um guardião dos contratos e da ordem estabelecida, o que, segundo Lima, é o terceiro fundamento do pensamento liberal burguês; pois que, o Estado intervém como estimulador de uma cultura cívica.

Não se trata do Estado defendido pelo neoliberalismo, nem do Estado grande, medido pelo número de funcionários e pelo tamanho do seu orçamento, mas de um Estado forte e ativo para fomentar empreendedorismo e a responsabilidade social dos indivíduos, grupos e empresários sociais. Buscando sua base de fundamentação teórica e política em Durkheim, Giddens critica as conseqüências sociais da ausência de regulação moral da esfera econômica. 0 papel do Estado, que se confunde com o governo, é garantir a regulação moral do mercado, espaço da eficácia econômica, da livreconcorrência e da liberdade individual. (Lima, 2007, p.62) 


\section{trabalhonecessário}

issn: $1808-799 \mathrm{X}$

ano 8 - número 10 - 2010

A referida autora afirmou que é nesse contexto que o conceito de governança ou governação é apresentado e, para além da ação política de um governo, vai significar "a capacidade reguladora que articula a esfera estatal e a esfera privada (base de fundamentação do conceito de público não-estatal) em âmbito nacional e internacional” (idem, p.63). Para Lima, é a partir dessa nova significação conceitual disseminada pelas políticas públicas dos Estados capitalistas que adotaram o neoliberalismo da Terceira Via (como fez o Brasil no governo de FHC com a reforma, ou melhor, a contrarreforma do Estado), que houve a necessidade de sustentar o projeto hegemônico com a construção de uma agenda capaz de viabilizar a reforma das funções e do tamanho do Estado e da relação estabelecida entre o Estado e a sociedade civil, de modo a garantir a governança. Podemos observar essa agenda e as orientações sobre reformas a serem realizadas pelos Governos, em alguns documentos da OCDE. Dentre eles, destacamos o "Principles of Corporate Governance", traduzido com o título "Os princípios da OCDE sobre os governos das sociedades" (OCDE, 2004) e, especificamente, em relação ao governo Lula, nos chamou a atenção o documento "Estudos Econômicos da OCDE Brazil 2005" (OCDE, 2006b). Tal organismo analisou as ações do Governo e fez avaliações sobre os temas sociais, o acesso ao crédito no sistema financeiro, as reformas microeconômicas e o marco regulatório, tratando da expansão do setor energético e das parcerias público-privadas para todas as áreas, especialmente a social, sugerindo o aumento de políticas focalizadas. A partir dessa discussão, a OCDE identificou os principais avanços e as maiores dificuldades na área social e econômica e fez recomendações quanto aos possíveis caminhos que o Governo poderia vir a seguir para garantir um crescimento estável e equitativo.

Para a Terceira Via, a sociedade civil tem uma importância política fundamental porque funciona como zona de ajuda mútua e solidariedade, que dá fundamento à noção de cidadania veiculada pelo novo projeto societário burguês onde a diluição das fronteiras entre o público e o privado seja 


\section{trabahonecessário}

issn: $1808-799 \mathrm{X}$

ano 8 - número 10 - 2010

compreendida apenas como um espaço público, espaço comum. As principais atribuições da sociedade civil seriam:

[...] de controle público da esfera estatal; prevenção da violência pelo incentivo da ação de grupos de auto-ajuda; do estímulo à família; do incentivo ao desenvolvimento físico de indivíduos e grupos sociais, articulando liberdade individual com solidariedade e responsabilidade social para a criação de um sistema moral capaz de garantir o pleno exercício das ações físicas; e da harmonização social por meio de um pacto para a promoção de um bem comum. (Lima, 2007, p.63)

Lima afirmou que, na visão da Terceira Via, as sociedades contemporâneas são constituídas de três esferas autônomas: o Estado, que exerceria uma ação reguladora das ações sociais constituindo-se num instrumento de coerção (Lima, 2007); o mercado, por sua eficácia do ponto de vista econômico e da liberdade individual, ou seja, da livre-concorrência e obtenção de lucro, da acumulação de capital; e a sociedade civil ativa, como uma instância solidária capaz de mediar a ajuda mútua tomando para si, em geral, tarefas que antes eram do Estado e, ao mesmo tempo, mediando a coesão cívica para diluir o conflito entre as classes sociais (idem, p.63).

Segundo a referida autora, na busca dessa coesão social que amenize os embates da luta de classes, a Terceira Via procura desqualificar as iniciativas coletivas de sindicatos classistas e partidos que busquem a superação da ordem burguesa. Mantendo a mesma premissa neoliberal, ressignifica os sujeitos coletivos por intermédio da refuncionalização com vistas a reduzir suas demandas em nível econômico e corporativo; além de criar novas formas de organização e participação social, tais como: ONG, conselhos público-privados, trabalho voluntário. Além disso, "propõe a democratização da democracia por meio de plebiscitos eletrônicos e júris de cidadãos" (idem, p.64), como forma de organizar um programa político que seja capaz de conceber o diálogo como meio de obter a conciliação dos irreconciliáveis 


\section{trabalhonecessário}

issn: $1808-799 \mathrm{X}$

ano 8 - número 10 - 2010

interesses do capital e do trabalho, procurando obter o consentimento passivo e ativo dos trabalhadores cooptados para o projeto burguês.

Para tanto, a Terceira Via faz da educação, tal como o liberalismo e o neoliberalismo, um instrumento de (con)formação dos trabalhadores (R. Souza, 2009). A educação é cada vez mais controlada, difundida e gestada pelo Estado, por organismos internacionais e pela burguesia, por intermédio de reformas que, na verdade, são "contra-reformas" (Lima, 2007) estruturadas para formar, conformando trabalhadores disciplinados, alienados, repolitizados e desintelectualizados o suficiente para não aderir a nenhuma Práxis que vise o coletivo para contrariar a ordem estabelecida pela burguesia. "Educar, no sentido restrito escolar, como formação técnico-operacional e ético-política do novo trabalhador-cidadão e, em sentido amplo, para coesão social, são tarefas da Terceira Via para o novo milênio" (Lima, 2007, p.64), e educar o novo cidadão é uma estratégia para evitar que a classe trabalhadora organize uma revolução contra o Estado (Lenin, 2007). Mas qual o novo sentido de cidadão para a nova social-democracia ou o neoliberalismo da Terceira Via? O que este projeto procura formar nos bancos escolares e universitários? Segundo Giddens (2008, p.78, apud Lima, 2007, p.64) o projeto de cidadania da Terceira Via vislumbra que "A principal força de desenvolvimento de capital humano obviamente deve ser a educação. É o principal investimento público que deve estimular a eficiência econômica e a coesão cívica". Para Lima, é esclarecedor quanto ao projeto da Terceira Via, quando afirma que o mesmo:

[...] evidencia que o projeto burguês de sociabilidade tem demonstrado ser capaz de realçar o velho sobre a aparência do novo. Esta capacidade, entretanto, não significa que as crises e contradições do capitalismo estejam superadas, mas reinscreve no horizonte político a construção do socialismo e a tarefa de desmontar os projetos que estão sendo apresentados como agenda possível dentro do capitalismo "reformado" ou "humanizado", que com seu discurso de profunda ambigüidade (socialismo de mercado e democratização da democracia ou radicalização da democracia) oculta o foco central do debate: os embates entre os projetos antagônicos de sociabilidade. (Lima, 2007, p.64) 


\title{
trabalhonecessário
}

issn: $1808-799 \mathrm{X}$

ano 8 - número 10 - 2010

É sobre esta premissa que Lima e outros autores afirmam que o projeto educacional em curso, de FHC a Lula, visa estabelecer a "pedagogia da hegemonia", na medida em que o Estado é concebido como instância educadora (Neves, 2005, p.20-21).

\begin{abstract}
O Estado, não sem tensões e contradições, vem intensificando, com todos os instrumentos legais e ideológicos, a seu dispor, o seu papel de educador, ou seja, de instrumento de conformação cognitiva e comportamental do brasileiro ao projeto de sociabilidade burguesa implementado pelos governos anteriores. O governo Lula da Silva vem se propondo a realizar um pacto nacional, ou em outros termos, a submissão consentida do conjunto da sociedade às idéias, idéias e práticas da classe que detém a hegemonia política e cultural no Brasil de hoje, por intermédio de sua reeducação técnico-ético-política. (Neves, 2005, p.95)
\end{abstract}

Para Neves (2005, p.69), o Estado junto aos organismos internacionais e esferas da sociedade civil compõem o novo bloco histórico que vem intervindo no plano político, buscando estabelecer, também pela educação, novos rumos da produção das relações político-sociais com vistas à legitimação dos padrões sociais vigentes. E ainda, segundo Neves, essa legitimação da nova cultura cívica do neoliberalismo da Terceira Via realiza-se por meio de três aparelhos privados de hegemonia: a mídia, a escola e as igrejas (2005, p.99). Suas ações são voltadas para a responsabilidade social e, a nosso ver, no caso da escola, com essa responsabilidade social materializando-se numa enxurrada de produções acadêmicas e exigências das Fundações e Secretarias de Educação de que tais instituições contemplem um "Projeto Político Pedagógico", antes de mais nada, para atender às carências sociais das comunidades do entorno.

P. Melo e Falleiros (2005) apontaram que o neoliberalismo da Terceira Via, no período de FHC a LULA, procurou organizar novas estratégias de legitimação social por meio da reforma da aparelhagem estatal, coordenada pelo Ministério da Administração e Reforma do Estado (MARE) encabeçada 


\title{
trabalhonecessário
}

issn: $1808-799 \mathrm{X}$

ano 8 - número 10 - 2010

pelo intelectual orgânico do capital Bresser-Pereira (1997). Os referidos autores afirmaram que entre 2003 e 2004 houve um aprofundamento do modelo de Estado neoliberal da Terceira Via com a vitória do Partido dos Trabalhadores (PT) na medida em que esse não rompeu com o projeto de modernização do Brasil baseado no equilíbrio macroeconômico, no controle fiscal e na reforma neoliberal do Estado. Ao contrário, aprofundou o processo, na medida em que buscou realizar um "novo contrato social" (idem, p.188-189), criando instituições de democracia direta para consultar a população em busca de obter o consenso. Paralelamente, o governo Lula foi implantando, inúmeras medidas provisórias, decretos, portarias e leis passíveis de consulta à sociedade civil:

\begin{abstract}
O aprofundamento da reforma da aparelhagem administrativa do Estado -por meio de reformas da previdência, tributária e trabalhista, bem como mediante a promoção de políticas de concorrência e 'reavaliação e implementação de marcos regulatórios relativos à infraestrutura econômica, com especial atenção ao impulso sobre os investimentos e ao estabelecimento e acompanhamento das tarifas que afetam a população menos favorecida' (BRASIL, 2003b, p.15) atrela-se a consideração de que, neste estágio de desenvolvimento do projeto neoliberal da Terceira Via no Brasil, o investimento público é 'fundamental na ampliação da infra-estrutura, essencial para viabilizar um movimento sustentado de crescimento' , embora não seja possível deixar de lado o seguinte imperativo: 'no atual contexto de restrição fiscal, o espaço para a ampliação do investimento público será relativamente limitado nos próximos anos. (Brasil, 2003b, p.6, apud P. Melo \& Faleiros, 2005, p.190)
\end{abstract}

Essa limitação do investimento público realmente deu-se nos anos subsequentes, especialmente na área social, educação e saúde, as quais passaram a "contar" com investimento privado, na medida em que o MARE (Bresser-Pereira, 1997) viabilizou de vez a diluição, especialmente em termos de financiamento, entre a coisa pública e a privada, criando uma nova nomenclatura: o público não-estatal.

Segundo Lima (2007), no leque de contrarreformas, o governo Lula reordenou o papel do Estado seguindo a política dos organismos 


\section{trabalhonecessário}

issn: $1808-799 \mathrm{X}$

ano 8 - número 10 - 2010

internacionais, especialmente do Banco Mundial, aprofundando o processo de privatização dos serviços públicos, em especial da educação superior (BM, 2004). Seguiu-se um pacote de contrarreformas que contrariaram a expansão da universidade pública, gratuita e de qualidade para a classe trabalhadora, garantindo, em seu lugar, a expansão do empresariamento da educação (Neves, 2002); o alargamento do processo de mercantilização da educação superior, acirrando sua concepção de mercadoria a ser vendida/comprada, principalmente com a ascensão das Tecnologias da Informação e Comunicação (TIC), meio pelo qual a Educação à Distância (EaD) expandiu-se atingindo em cheio a formação de professores; o cumprimento do Acordo de Bolonha visando, por intermédio da internacionalização da educação superior, expandir a diplomação compartilhada (dando origem ao Processo de Bolonha); o beneficiamento de empresas de serviços educacionais com a compra de pacotes educacionais e material didático; a salvação das indústrias através da venda de kit's tecnológicos para escoar a produção, principalmente dos países da OCDE; e a ampliação do comércio das empresas de softwares por meio dos provedores de internet, instrumento utilizado pela EaD.

Enfim, o pacote de contrarreformas na educação superior foi implantado seguindo a cartilha dos organismos internacionais: diversificação das instituições de ensino superior e das fontes de financiamento das universidades públicas, mobilizando fundos privados; o uso das TICs como estratégia para diversificar as instituições e fontes de financiamento (Lima, 2007, p.70). Significa dizer que o governo Lula organizou a contrarreforma da educação superior de modo a viabilizar a mercantilização da educação, pressuposto básico para a expansão do capital.

Nesse contexto, influenciando as ações em território nacional, na nova ordem mundial, a Organização Mundial do Comércio (OMC) procurou, por meio do Acordo Geral sobre Comércio em Serviços (AGCS), liberalizar e reduzir as barreiras de comércio mundial de modo a reduzir e/ou eliminar as tarifas e também "limitar as importações pela imposição de cotas e salvaguardas dos 


\section{trabalhonecessário}

issn: $1808-799 \mathrm{X}$

ano 8 - número 10 - 2010

mercados locais, garantindo o controle de acordos sobre liberalização comercial de serviços" (Siqueira, 2004, p.71).

Essas mudanças foram impulsionadas pelos organismos internacionais, criados para a condução da crise do capital nos anos 50 e 60 . O Acordo de Bretton Woods e o desenvolvimentismo na América Latina foram impulsionados pela facilidade de obtenção tanto de empréstimos quanto de investimentos externos diretos, o permitindo que a burguesia internacional defendesse seus interesses participando da correlação de forças sociais independentemente da Particularidade dos sistemas institucionais e organização jurídica de cada país. Para Melo (2004), outra conseqüência das intensas mudanças na forma de reprodução do sistema capitalista foi a montagem do Welfare state, ou seja, da política de Estado de bem-estar social. Segundo Oliveira (1998, p. 19-20), o Welfare foi desencadeado pela política keynesiana que construiu um padrão de financiamento público da economia "o fundo público em suas diversas formas passou a ser o pré-suposto das diversas formas de financiamento do capital, de um lado, e, de outro, do financiamento da reprodução da força de trabalho atingindo globalmente toda a população por meio dos gastos sociais" (idem). Tanto Oliveira (1998) quanto Silva Júnior (2002) defenderam a ideia de que a política de Estado de bemestar social foi uma forma de expressão de um Estado burguês, que procurou valorizar o capital pela esfera do social, principalmente com a política do pleno emprego. O Estado, influenciado, sobretudo, pelas necessidades da nova sociedade urbana e também pelo desenvolvimentismo, por meio dos serviços, passou a ser o maior empregador de mão de obra, tornando-se instância viabilizadora da valorização de capital pela relação fundo público / capital privado /reprodução da força de trabalho (Oliveira, 1998, p.21).

Quanto à educação propriamente dita, essa valorização deu-se, segundo Silva Júnior (2002), sob duas formas imediatas e uma mediata. A primeira forma, considerada imediata, pelo consumo de insumos básicos da educação, tais como material didático e paradidático, que hoje constitui toda a sorte de material oriundo da área de ciência e tecnologia da informação (CTI), 


\section{trabalhonecessário}

issn: $1808-799 \mathrm{X}$

ano 8 - número 10 - 2010

como, por exemplo, os computadores. A segunda forma imediata, de acordo com Silva Júnior (2002), seria por meio do pagamento dos professores, pois a maior categoria do funcionalismo público ainda é a docente.

Na forma mediata, a reprodução do capital se dá pelas isenções fiscais ou pelo desvio dos fundos públicos para manutenção da atividade pública- não estatal, ou seja, à época, no caso brasileiro, deu-se pelos empréstimos do Estado para subsidiar a expansão do setor privado na área da educação. Atualmente, com o empresariamento da educação superior (Neves, 2002), a reprodução veio-se expandindo, desde a década da educação (1990), prioritariamente pelas mãos dos cursos de formação de professores na modalidade à distância. Para Lima (2007), esse tema precisa ser entendido na dinâmica da nova sociabilidade. A referida autora afirmou que o projeto de dominação possui duas faces distintas:

[...] que se apresentam a partir da acepção globalização econômica ou da constituição de uma nova sociedade, a sociedade da informação. O papel dos organismos internacionais na difusão e elaboração dos valores e concepções que constituem esse projeto de dominação tem sido fundamental. As políticas promovidas por estes sujeitos políticos coletivos do capital - Grupo BM, Unesco e, mais recentemente, a OMC -vêm orientando um conjunto de reformas econômicas e políticas realizadas nos países da periferia do capitalismo. Neste conjunto de reformas neoliberais, que articula a reestruturação da esfera produtiva, o reordenamento do papel dos Estados nacionais e a formação de uma nova sociabilidade burguesa, estão isentas as reformas educacionais realizadas nos países periféricos e que atravessaram o final do século $X X$ e se estenderam pelo início do século XXI. (Lima, 2007, p.51)

Esse projeto burguês de sociabilidade, difundido pelos organismos internacionais, estaria fundamentado, para a referida autora, em três "nucleações temáticas" (LIMA, 2007, p. 52-53). A temática "A" diz respeito à política elaborada pelo binômio pobreza/segurança, com função de criar uma imagem de possível integração dos países periféricos, mediante a adequação às políticas de ajuste impostas pelo Grupo dos Sete (G7), principalmente pelo 


\section{trabalhonecessário}

issn: 1808-799X

ano 8 - número 10 - 2010

imperialismo estaduniense. Para isso os organismos internacionais criam o discurso de enfrentamento da pobreza, um alívio de caráter instrumental, cujo objetivo é camuflar a busca por legitimidade e segurança para manter a reprodução global do capital.

A temática "A", também remete-nos a questão da "globalização econômica" como sustentáculo da ideologia burguesa, como elemento político central para manutenção do imperialismo estaduniense, como afirmou Lima (2007). Desde 1970, quando a crise do sistema capitalista eclodiu no processo de "globalização", o capital assumiu novas formas de organização, utilizando estratégias de descentralização e desterritorialização para, assim, incorporar gradualmente, todas as formas de capital, fossem elas de origem industrial, financeira ou comercial (Boito Júnior, 1999). O termo globalização é de origem francesa e, segundo Chesnais (2005) pode ser definido como a capacidade estratégica de um grande grupo oligopolista, voltado para a produção manufatureira ou produção de serviços, em adotar por conta própria, livre da regulação do Estado, uma conduta global, principalmente na esfera financeira. Essa é uma forma de integração de mercados financeiros com a estratégia de abertura dos mercados nacionais via liberalização de capital, desregulamentação de setores estratégicos da economia e desregulamentação fiscal.

A temática " $\mathrm{B}$ " se refere às políticas dos organismos internacionais que procuram reafirmar a promessa inclusiva da educação para os segmentos pauperizados pelo aprofundamento das desigualdades econômicas. Nesse projeto, a noção de capacitação, especialmente a capacitação tecnológica, é apresentada como mediadora da inclusão, um passaporte para a empregabilidade. Para Lima (2007), é nesse sentido que a reforma educacional imposta pelos organismos articula uma retomada da Teoria do Capital Humano (TCH) - pelo do discurso de investimento em capacidades, habilidades e competências - associada à teoria do capital social (a ação de grupos voluntários, de ONGs e da responsabilidade social do empresariado); viabilizaria a execução e o financiamento compartilhados da política 


\section{trabalhonecessário}

issn: $1808-799 \mathrm{X}$

ano 8 - número 10 - 2010

educacional. Para tanto, segundo Chesnais (1996), Estados, grupos empresariais e organismos internacionais como a OCDE têm procurado promover, ao máximo, o processo de internacionalização das companhias de serviços, as quais, por sua vez, consomem e movimentam o setor industrial. $O$ Investimento Externo Direto (IED) do capital foi organizado, na maioria dos países, com base no serviço público e no setor financeiro por meio dos processos de liberalização e desregulamentação das legislações nacionais.

No tocante à educação, Siqueira (2005, p.3) afirma que a internacionalização diz respeito também a um processo de colonização por meio do controle do conhecimento e não de cooperação acadêmica, e para além, "a tônica em todos os documentos tem sido o da competição, da defesa e ampliação do mercado através da educação à distância, de cursos com menor duração, de convênios, etc", principalmente nos documentos produzidos após o Processo de Bolonha. Em junho de 1999, vinte e nove ministros de países da Europa elaboraram a Declaração de Bolonha, "cujo objetivo central era uniformizar o sistema de ensino superior europeu, visando à mobilidade $\mathrm{e}$ empregabilidade no espaço europeu" (Lima, 2007, p.69). A ideia de formar uma "Europa do conhecimento", posta na Declaração de Bolonha, indica, segundo Lima, um conjunto de reordenamentos no mercado de trabalho e, consequentemente, a formação e a qualificação dos trabalhadores. Exigiu-se a diversificação das fontes de financiamento da educação superior e a diversificação das instituições/cursos superiores.

A educação superior é concebida nos marcos da empregabilidade dos trabalhadores; uma formação voltada para o mercado de trabalho, por meio da realização de cursos de curta duração; a eliminação de obstáculos que ainda existiam à total mobilidade de estudantes (assim como os estagiários e diplomados) e professores (assim como de investigadores e administradores de ensino superior); utilização das TIC por meio da EAD e a estandardização ou uniformização dos currículos. Este debate foi retomado em maio de 2001, na Conferência de Praga, e em setembro de 2003, em Berlim, quando ficou estabelecido o ano de 2005 para a realização do Sistema de Transferência de Crédito Europeu. (Lima, 2007, p.69) 


\title{
trabalhonecessário
}

issn: $1808-799 \mathrm{X}$

ano 8 - número 10 - 2010

A mercantilização da educação é um resultado do processo de internacionalização, na medida em que serve para reestruturar, reorientar e redesenhar as universidades, adaptando-as aos padrões estrangeiros (países centrais) desde a estrutura à importação de cursos e currículos adaptados, organizando uma rede de compra e venda de diplomas compartilhados.

\begin{abstract}
Em termos de "internacionalização" é importante ressaltar outros atores, como as grandes corporações educacionais, como as norteamericanas Sylvan Learning Systems e Grupo Apollo, que em 2000 apresentaram resultado de exportação de serviços educacionais da ordem de 10,3 bilhões de dólares (SAUVÉ, 2002). Segundo SCHUGURENSKY e DAVIDSON-HARDEN (2003, p.342), o Sylvan tem atuado no México, com interesse majoritário na Universidad del Valle, tendo adquirido universidades privadas no Chile, na Espanha, na França e na Suíça O Grupo Apollo, atua nos EUA e no Canadá através da University of Phoenix e também na America Latina, sendo que no Brasil tem parceria com o Grupo Pitágoras. No Canadá KACHUR (p.382) destaca que o segmento que mais cresce na economia canadense é 0 denominado de "indústria do conhecimento", que também vem apresentando um importante papel no aumento das exportações daquele país. Na Austrália, é corrente tratar o setor universitário como "setor de negócio" e o termo "universidade empresarial" para descrever 0 caráter das universidades australianas. (Siqueira, 2006, p.2)
\end{abstract}

Empresários da educação superior e o Estado inovam tornando o que é público em privado, e privado em coisa pública. A criação do padrão de acreditação das instituições de ensino superior que, no Brasil, vem sendo organizado por meio do SINAES, nada mais é do que uma forma de regulamentar de dentro para fora - adaptar - para ampliar a concorrência nacional e internacional. Para Siqueira, os dois organismos internacionais à frente do processo são o Banco Mundial e a Unesco:

O Banco Mundial volta a querer se apresentar como Banco do Conhecimento, o que foi postulado num documento de 1999 'Education Sector Strategy' e depois abandonado após severas críticas, mas que no documento de 2002, além desse perspectiva de 


\title{
trabalhonecessário
}

issn: $1808-799 \mathrm{X}$

ano 8 - número 10 - 2010

\begin{abstract}
Banco do Conhecimento, há todo um discurso articulado com o Acordo Geral sobre o Comércio em Serviços (AGCS ou GATS) no âmbito da Organização Mundial do Comércio (OMC) e com grupos empresariais, em termos de eliminação de barreiras 'desnecessárias' (regulamentações nacionais) ao acesso (venda) dos conhecimentos. Cabe destacar que a UNESCO vem dando grande suporte a este processo, trabalhando em conjunto com o Banco Mundial, com profissionais ligados a EUREK - principalmente para a implantação do Processo de Bolonha, da ERA, do EURAB, etc. - numa perspectiva de centralização cada vez maior das decisões, modelos e práticas institucionais. (Siqueira, 2006, p.2)
\end{abstract}

A internacionalização do capital funciona, também, como uma política mediadora da Práxis burguesa de manutenção da hegemonia pela conciliação entre classes para garantir a expansão do mercado e a manutenção das taxas de lucro. O investimento internacional, por meio do comércio exterior, como o intercâmbio e produção de bens e serviços, dentre eles a educação, garante ao capital uma reprodução pela área social (Silva Júnior, 2002), movimentando um verdadeiro comércio internacional. No que refere-se ao setor de serviços, Chesnais (2005) diz que a previdência privada foi a área mais visada pelo capital financeiro desde a década de 1970, tornando-se um mercado aberto mediante o perdão da dívida pública e, nesse pacote, a educação, na nossa hipótese, foi incorporada como meio de aliviar os gastos do Estado, facilitando o pagamento da dívida pública, travando-se um espaço privilegiado para a exploração do capital.

A temática "C" refere-se à subordinação da educação às exigências da lucratividade do capital internacional. O projeto hegemônico defende a argumentação de que tanto as instituições públicas quanto as privadas prestam serviços públicos. Os conceitos de público e privado foram diluídos pela noção de público-não estatal; paralelamente, o mesmo projeto burguês considera as escolas e as instituições de ensino superior como prestadoras de serviços e formadoras da força de trabalho e do exército de reserva a fim de atender às novas demandas criadas pelo reordenamento no mundo do capital: 


\title{
trabalhonecessário
}

issn: $1808-799 \mathrm{X}$

ano 8 - número 10 - 2010

\begin{abstract}
Neste sentido, tanto a perspectiva claramente comprometida com a transformação da educação em serviço (BM e OMC) como a perspectiva que critica essa lógica, defendendo a educação como um descaracterizado bem público (UNESCO), criam as bases para a educação, especialmente a educação superior, torne-se um promissor campo de exploração. Nas duas perspectivas, identifico a utilização das TIC como um dos principais mecanismos desta mercantilização, ainda que essa utilização, por meio da educação à distância (EAD), apareça como uma estratégia de "internacionalização" e de "democratização" do acesso à educação ao longo da década de 1990 e início do novo século. (Lima, 2007, p.53)
\end{abstract}

A temática "C", também remete-nos aos enfrentamentos da educação como campo de criação de exploração. A área vem sofrendo mutações para atender às demandas da financeirização global (Fiori \& Tavares, 1998). O conceito de financeirização global diz respeito à: 1) formação de um novo padrão sistêmico com a paridade ouro/dólar em meados dos anos 60;2) criação das grandes corporações capitalistas que introjetaram estratégias de concorrência com ênfase no progresso técnico e de investimento produtivo, entre empresas industriais voltadas para a competição internacional, caracterizando um cenário de políticas de ajuste e reestruturação produtiva coexistindo com a globalização; 3) macroestrutura financeira que comporia 0 padrão sistêmico da financeirização - um lócus privado e público (Fiori \& Tavares, 1998, p.195-242) - concretizado pelas grandes corporações, bancos, empresas financeiras, investidores institucionais e dos bancos centrais dos países líderes (G7) que movimentam a riqueza mobiliária por meio das operações com moedas e títulos.

\footnotetext{
A financeirização como padrão sistêmico de riqueza é uma forma específica pela qual há mais de quatro décadas se faz a definição (moeda-crédito-patrimônio), gestão (macroestrutura financeira) e realização da riqueza (dinheiro e ativos financeiros predominantes sobre os operacionais) num número crescente de países. É um modo de ser do sistema, historicamente determinado, sustentável em longos prazos. As chamadas "bolhas especulativas" são "picos exacerbados", cujo potencial de desordem a intervenção públicoprivada, na macroestrutura financeira tenta minimizar, financiando posições de empresas e governos para evitar o "crash" generalizado, "coordenando", neste movimento, a desvalorização momentânea da
} 


\section{trabalhonecessário}

issn: $1808-799 \mathrm{X}$

ano 8 - número 10 - 2010

capitalização financeiro-patrimonial, que volta a se repor, dada a natureza da dinâmica sistêmica. (Fiori \& Tavares, 1998, p. 239)

Ressaltamos que um dos problemas centrais que atingem as políticas públicas nacionais é a transformação das finanças públicas em reféns dos mercados pela da manutenção da dívida pública financeirizada, na medida em que são aceitos investimentos privados na esfera pública e vice-versa. A priorização do pagamento da dívida externa inteira e o sustento deste processo que medeia a reprodução do capital trouxeram o enxugamento do Estado na área social, afetando, principalmente, a saúde e a educação. Já afirmamos, em sessão anterior, que o Banco Mundial e o FMI, nas últimas duas décadas, vêm negociando a ampliação do "mercado educacional" mediante o pagamento da dívida pública, trocando parte desta por uma abertura para investimentos do capital privado, como auxiliar da expansão da educação básica, e, ao mesmo tempo, regulador e multiplicador do ensino superior privado.

Fica, então, a educação, como serviço, bastante viabilizada pelo processo de internacionalização/comercialização da educação superior em escala mundial. A nosso ver, a OCDE tem interesse direto nesse processo na medida em que agrega diversas formas de capital privado e estabelece acordos entre empresários, sindicatos, Estados e outros organismos internacionais.

\section{AS ORIENTAÇÕES DA OCDE E AS AÇÕES DO GOVERNO LULA: UM EXEMPLO DA DOMINAÇÃO EXTERNA}

Partindo do trabalho da Luiz de Mello (2005), coordenador da Subdivisão para a América Latina e no País, departamento de economia da OCDE, na conferência realizada em 2005 no Brasil, observamos a recomendação explícita da OCDE: o Brasil precisava levar a cabo algumas reformas políticoeconômicas. A pesquisa desse organismo apontou que no quadro de ajuste 


\section{trabalhonecessário}

issn: $1808-799 \mathrm{X}$

ano 8 - número 10 - 2010

macroeconômico, as reformas foram consideradas insuficientes, apesar da administração da dívida pública ser exemplar, no governo Lula. As políticas monetárias também foram consideradas insuficientes e, diante desse fato, a OCDE fez três recomendações ao Governo para vencer o desafio de obter estabilidade macroeconômica:

[...] reequilibrar o ajuste fiscal, privilegiando a contenção do gasto corrente, viabilizando a introdução de limites para o gasto corrente, reformas paramétricas adicionais na Previdência, redução da rigidez orçamentária (desvinculação de receitas), DRU, ICMS; fortalecer a administração da dívida pública; aumentar a eficiência da política monetária via eliminação gradual do crédito direcionado e das reservas compulsória. (OCDE, apud Melo, 2005) (grifos nossos)

Para a OCDE, obter uma mão de obra mais qualificada exigiria aumentar a instrução do trabalhador. Segundo Mello (2005), as últimas recomendações da OCDE ao Governo foram: "facilitar a entrada das mulheres no mercado de trabalho; desincentivar a aposendoria precoce e a inatividade por doença/invalidez; reduzir a informalidade no mercado de trabalho; tornar a qualificação profissional mais atrativa" (idem, p.29). Entendemos que a busca pela elevação dos níveis de investimento nas parcerias público-privadas, para que o Governo pudesse ampliar a implantação de políticas focalizadas em favor dos mais pobres, vislumbrando a acumulação de capital humano, ou seja, mão de obra para atender ao mercado e garantir a coesão social. Identificamos no trecho citado a seguir a orientação de que as políticas focalizadas sejam realizadas paralelamente, com a manutenção do processo de diminuição do Estado na área social, e entendemos que essa questão precisa ser analisada. Segundo Melo e Faleiros (2005), isso caracteriza uma política baseada no neoliberalismo da Terceira Via por não barrar de forma alguma a redução do Estado, apenas instituindo uma política de "alívio da pobreza": 


\title{
trabalhonecessário
}

issn: $1808-799 \mathrm{X}$

ano 8 - número 10 - 2010

As políticas sociais deverão, portanto, ser fortalecidas de modo a contribuir para o cumprimento da agenda social do governo priorizando programas sociais considerados mais eficientes $e$ voltados para a acumulação de capital humano ao mesmo tempo em que se mantém a disciplina fiscal e se consolida o apoio da sociedade às reformas estruturais. (OCDE, 2006b, sumário executivo)

O discurso da OCDE sobre as políticas sociais se remeteram também à questão da exclusão social colocando a educação, como única responsável pela exclusão da classe trabalhadora do mercado de trabalho. A própria OCDE tratou de sugerir a mediação do consenso, organizando, assim, uma estratégia de manutenção, formando uma amálgama de interesses da burguesia em geral, sem fronteiras entre o nacional e o internacional:

\begin{abstract}
Parece a ver um amplo consenso dentro e fora do governo quanto à ideia de que as disparidades sociais não permitem que os benefícios do crescimento sustentado sejam repartidos igualmente entre os diferentes grupos sociais. A exclusão social impede os grupos vulneráveis de adquirirem qualificações adequadas às demandas do mercado de trabalho, o que contribui para o alto nível de desemprego e informalidade entre esses grupos, além de perpetuar a desigualdade na distribuição de renda. (OCDE, 2006b, p.5) (grifos nossos)
\end{abstract}

Para a OCDE, a agenda do governo Lula deve prosseguir realizando contrarreformas que permitam a reprodução do capital na esfera social, e, para tanto, a avaliação da educação nacional deve caminhar segundo a ditadura dos indicadores sociais dos países da OCDE. A educação aparece, na proposta, como campo de convencimento da sociedade sobre a necessidade de contrarreformas no Estado que flexibilizem a legislação, tornem economicamente eficiente os gastos sociais e abram as portas para o capital privado auxiliar o Governo na prestação de serviços: 


\section{trabalhonecessário}

issn: 1808-799X

ano 8 - número 10 - 2010

O principal desafio a esse respeito é fortalecer as políticas sociais que irão permitir o cumprimento da agenda social do governo e ao mesmo tempo manter a disciplina fiscal e consolidar o apoio da sociedade à continuidade das reformas estruturais. Muito tem sido feito na área social na última década, com melhorias incontestáveis nos principais indicadores sociais, principalmente na área de educação. Mas, apesar disso, o governo continua a ter um papel importante a desempenhar, assegurando que os indicadores sociais sejam compatíveis com as despesas já bastante altas com programas sociais, incluindo aposentadorias. As despesas do governo geral com programas sociais - incluindo educação, saúde, habitação e urbanização, seguridade e assistência sociais, e seguro-desemprego - representam cerca de $25 \%$ do PIB, bem acima do padrão de despesas observado em países com um nível de renda comparável ao do Brasil. Devido a esse alto nível de despesa, a ênfase das políticas públicas deve ser redirecionada paulatinamente para o aumento da eficiência dos programas sociais, calcada na continuidade por meio do fortalecimento gradual dos programas já existentes e na melhoria dos serviços prestados. (OCDE, 2006b, p. 12-13) (grifos nossos)

A preocupação da OCDE com os gastos sociais do Governo com aposentadorias - prioritariamente as do funcionalismo público - também faz parte de uma estratégia que visa a abrir tais setores ligados à previdência, sugerindo o aprofundamento da contrarreforma da previdência social. Segundo Chesnais (2005, p.51), os fundos de pensão são de interesse extremo para o capital financeiro (especialmente da OCDE), porque, na previdência por capitalização, estes acumulam as contribuições calculadas sobre os salários e vencimentos dos trabalhadores, fazendo da poupança acumulada um capital. Nesse sentido, há um grande interesse em expandir o setor de serviços por meio de instituições financeiras não bancárias, fazendo com que os trabalhadores assalariados, diante da prestação dos serviços sociais do Estado, ofertados de forma precarizada, optem em investir na previdência privada, por exemplo. A justificativa recai sobre a má distribuição de renda e a incapacidade nacional de manter o padrão dos países da OCDE. A OCDE reafirma que, "respeitando-se 0 atual envelope orçamentário, a sustentabilidade financeira do sistema de seguridade social deverá ser restabelecida para criar espaço no orçamento para maiores despesas com programas mais focalizados nas populações de baixa renda e no acúmulo de capital humano" (OCDE, 2006b, p. 51-57). A educação como meio de acumular 


\section{trabalhonecessário}

issn: $1808-799 \mathrm{X}$

ano 8 - número 10 - 2010

capital humano foi apontada por este organismo como justificativa da expansão do ensino fundamental em detrimento ao superior, pois a maior parte da população não possui a qualificação profissional esperada pelo mercado. Daí a política de avaliação dos sistemas de ensino ser erigida pelos organismos como o termômetro do desenvolvimento econômico atrelado à educação:

O ensino superior responde por cerca de um quinto das despesas governamentais com educação, o que está próximo à média da OCDE, mas o custo médio por estudante é de aproximadamente $150 \%$ do PIB per capita, cerca de três vezes superior à média da OCDE. Assim, a opção de aumentar a recuperação dos custos com o ensino superior por meio de um melhor direcionamento dos gastos públicos existentes em favor de instituições filantrópicas seria bem-vinda. (OCDE, 2006b, 51-57) (grifos nossos)

Outro ponto que ficou claro nos documentos da OCDE refere-se à futura mão de obra a ser explorada pelo capital. Entendemos que a participação do Brasil no programa da OCDE (PISA) denuncia que há tempos o Brasil participa de programas que objetivam monitorar a formação dos futuros quadros de mão de obra no país e o nível de investimento do capital estrangeiro na área da educação:

A focalização das despesas sociais de caráter universal, especialmente com educação e saúde, também pode ser aprimorada. Isto pode ser alcançado por meio do contínuo redirecionamento da despesa pública em favor da saúde preventiva e do ensino fundamental, que tendem a beneficiar mais a população de baixa renda. Por exemplo, a fração do PIB destinada às despesas públicas com educação está próxima à média da OCDE, mas, segundo a avaliação do projeto PISA da OCDE, o desempenho dos estudantes brasileiros é fraco em comparação com países que possuem níveis semelhantes de despesas públicas com educação." (OCDE, 2006b, 51-57)

Assim, justifica-se, pelas mãos da Avaliação dos Sistemas de Ensino, a abertura da escola como campo de exploração para a indústria com o uso das 


\section{trabalhonecessário}

issn: $1808-799 \mathrm{X}$

ano 8 - número 10 - 2010

Tecnologias da Informação e Comunicação (TICs) e também para a exploração dos empresários do ensino que fabricam cursos de aperfeiçoamento e gestão educacional, organizam a venda do sistema de apostilados e livros didáticos e etc. É desta forma que o capital se reproduz e, para tanto, necessita de que o Estado reduza as despesas com educação focalizando custos em setores estratégicos que garantam a conciliação mínima entre as classes sociais para a manutenção da ordem. O subterfúgio é fazer do ensino fundamental uma necessidade básica para a população de baixa renda, mantendo-a com um patamar mínimo de escolarização para acompanhar as mudanças na base técnica do trabalho e submeter-se à exploração. A proposta da OCDE distancia-se totalmente do patamar mínimo de educação que a LDB 9394/96 instituiu, propondo abertamente que a Educação Básica - que inclui educação infantil, ensino fundamental e ensino médio - fique restrita aos oito anos de escolarização. Proposta estapafúrdia, só não mais escandalosa que a do Banco Mundial (Siqueira, 2001; Torres, 2000), que entende compreender a educação básica para os países periféricos apenas os quatro primeiros anos de escolarização. Com base na análise de outro documento da OCDE sobre governança corporativa, intitulado "O governo das sociedades", publicado em 1999, concluímos que a OCDE, a Unesco e o Banco Mundial organizaram um pacto de controle sobre a educação superior, tomando-a como área frutífera para a expansão do capital.

A OCDE também destacou no texto a questão do investimento financeiro no ensino superior, deixando claro que a prioridade não é o investimento nas universidades públicas. Enfatizou, ainda, que a ampliação do acesso ao ensino fundamental deve ser realizada nos marcos da ordem, sem, no entanto, tratar de uma possível política de abertura de novas universidades públicas para garantir a continuidade da formação dos trabalhadores em nível superior. A OCDE aconselhou o Governo a continuar mantendo a política de Estado mínimo ao propor a contenção dos gastos por estudante e incentivando políticas focalizadas para contenção da pobreza e manutenção dos pobres dentro dos muros da escola com o programa Bolsa Família: 


\section{trabahonecessário}

issn: $1808-799 \mathrm{X}$

ano 8 - número 10 - 2010

Isso também é verdade para a maior ênfase, em termos de concepção e prestação de serviços, em programas de transferência focalizada de renda, incluindo os programas que fazem parte do Bolsa Família. Em reconhecimento ao fato de que a pobreza pode ser aliviada e que a distribuição de renda pode ser melhorada a longo prazo através do acúmulo de capital humano, o uso contínuo da freqüência escolar como condição para a inscrição em programas de transferência de renda é altamente aconselhável, bem como o monitoramento adequado do cumprimento das condicionalidades desses programas. (OCDE, 2006, p. 51-57) (grifos nossos)

Quanto à política destinada ao ensino superior, lócus de formação dos professores da educação básica, a OCDE critica os gastos excessivos, propondo o direcionamento de parte da verba para instituições filantrópicas leiam-se fundações, instituições que, por lei, podem captar recursos privados e do fundo público.

[...] do direcionamento das instituições públicas para a esfera privada através de fundações de direito privado, das cobranças de taxas e mensalidades, do corte de vagas para a contratação de trabalhadores em educação e do corte de verbas públicas para infra-estrutura das instituições, entre outros mecanismos. (idem, p.47).

Segundo Lima (2002), os discursos dos organismos internacionais primam pela redução das verbas públicas para a educação, como meio de fortalecer a expansão do ensino privado mediante a liberalização dos serviços educacionais. De FHC ao governo Lula, as "reformas" traduziram-se em estratégias de contrarreforma na educação superior para viabilizar a manutenção da ordem do capital. Uma avalanche de decretos, leis e portarias forjaram uma verdadeira contrarrevolução neoliberal, na qual a submissão do Brasil à ordem do capital foi mediada pela "hierarquização entre países centrais e a periferia do capitalismo e, simultaneamente, o papel fundamental que a burguesia brasileira e a burocracia sindical e partidária da classe trabalhadora 


\section{trabalhonecessário}

issn: $1808-799 \mathrm{X}$

ano 8 - número 10 - 2010

exerceram (e vêm exercendo) para o aprofundamento da submissão do Brasil à ordem do capital" (Lima, 2007, p.77).

Esse movimento contra-revolucionário, essa defesa autocrática gerou, ao longo do tempo, um ambiente propício para o capital da OCDE se infiltrar. Entendemos que o documento da OCDE sobre análise econômica do Brasil (2006b), em sua essência, traçou uma avaliação do desenvolvimento em termos de ambiente de investimentos para o empresariado e o capital financeiro, sendo que nos chamou atenção o fato da educação fazer parte de tal avaliação, principalmente porque o Brasil não é membro da OCDE. Isso confirma nossa hipótese de que, como os demais organismos internacionais, a OCDE busca abrir nichos de mercado, por meio da expansão do setor de serviços, na área da educação. Concluímos que da proposta dos organismos internacionais, especificamente a Unesco, o Banco Mundial, o FMI e a OCDE, sobre o perdão da dívida pública em troca de investimento na educação (LIMA, 2007), é o discurso que vela a essência das Práxis da OCDE que é abrir portas para a expansão do setor privado:

A conversão da dívida pública brasileira representa uma oportunidade de aumento dos investimentos em educação [...] Alternativas que complementem a conversão da dívida pública mobiliária, assim como a dívida privada, têm maior potencial de mobilização de recursos no caso brasileiro, mas requerem grande coordenação dentro do governo e com o mercado financeiro. (Cunha \& Souto, 2005, apud Unesco, 2005, p.19) (grifos nossos)

Afirmamos que para a OCDE essa inserção é fundamental porque, segundo o documento OECD Principles of Corporate Governance (OCDE, 2004 ), ou melhor, "Os Princípios da governança corporativa", traduzido para o português com o título "Os princípios da OCDE sobre os governos das sociedades": 


\section{trabalhonecessário}

issn: $1808-799 \mathrm{X}$

ano 8 - número 10 - 2010

Os Princípios destinam-se a ajudar os governos de Estados-Membros e países terceiros nos seus esforços para avaliar e melhorar o enquadramento legislativo, institucional e regulamentar o governo das sociedades nos respectivos países e a proporcionar linhas de orientação e sugestões para as bolsas de valores, investidores, empresas e outras partes [...] Os Princípios aplicam-se essencialmente às sociedades de capital aberto ao público, tanto financeiras como não financeiras. No entanto, na medida em que sejam aplicáveis, eles poderão ser uma ferramenta útil para melhorar o governo das sociedades com o capital fechado ao investimento do público, quer sejam empresas privadas ou empresas públicas. [...] Os accionistas [sic.] dominantes, que poderão ser pessoas singulares, empresas familiares, membros de sindicatos de bloqueio ou outras empresas que operem através de uma holding ou de participações cruzadas. (OCDE, 2004, p.11 e 12)

A coordenação dentro do Governo e sua relação com o mercado pautam-se na perspectiva da governança e foi explicitada no referido documento, compreendendo-se o Estado concebido como mediador da regulação política e econômica e da desregulamentação fiscal. A OCDE, ao organizar os acordos entre países e as mais variadas formas de representação da sociedade civil, utiliza-se da sua supralegislação, chamada "Estabelecimentos Permanentes de Direito Internacional" (Caliendo, 2005), para moldar e/ou modificar as legislações dos Estados-membros para atender aos interesses do capital por ela representado. É com essa finalidade que o Estado é concebido, além de conciliador dos conflitos entre o capital e o trabalho:

[...] os governos têm uma responsabilidade importante na definição de um enquadramento regulamentar eficaz que proporcione a flexibilidade suficiente para permitir aos mercados funcionarem de forma eficaz e responderem às expectativas dos accionistas [sic.] e de outros sujeitos com interesses relevantes. Compete aos governos e aos intervenientes no mercado decidirem como aplicar estes Princípios no desenvolvimento do seu enquadramento do governo das sociedades, tendo em conta os custos e os benefícios da regulamentação. (OCDE, 2004, p.14)

O grau de participação dos trabalhadores no governo das sociedades depende da legislação e das práticas adoptadas [sic.] a nível nacional, podendo variar igualmente de empresa para empresa. No 


\section{trabalhonecessário}

issn: $1808-799 \mathrm{X}$

ano 8 - número 10 - 2010

contexto do governo das sociedades, os mecanismos de optimização [sic.] do desempenho destinados a reforçar a participação dos trabalhadores podem beneficiar as empresas, directa [sic.] e indirectamente [sic.], dado que aqueles se mostrarão mais interessados em investir em competências especificamente adequadas à sua empresa. Alguns exemplos de mecanismos destinados a reforçar a participação dos trabalhadores incluem: representação dos trabalhadores nos órgãos de administração; e processos de governo, como comissões de trabalhadores, que levam em conta a opinião dos trabalhadores na tomada de determinadas decisões fundamentais. No que se refere aos mecanismos de optimização [sic.] do desempenho, podem encontrar-se em muitos países planos de aquisição de acções [sic.] pelos trabalhadores e outros sistemas de partilha de lucros. Os compromissos em matéria de pensões são também frequentemente uma componente da relação entre a empresa e os seus antigos e actuais [sic.] trabalhadores. Quando esses compromissos implicam a criação de um fundo independente, os seus administradores devem ser independentes do órgão de administração da empresa e gerir o fundo em prol de todos os beneficiários. (OCDE, 2004, p.48) (grifos nossos)

De acordo com o referido documento, as empresas nacionais ainda podem fazer parte das organizações da OCDE e tomar empréstimos mesmo que o país não seja membro efetivo. Caso haja falência, pode ficar acordado que o Estado deve responsabilizar-se por parte do pagamento da dívida. Assim a OCDE articula, em nível internacional, a "cooperação econômica total", num movimento que cria pactos entre outros organismos internacionais, Estados, empresários e até sindicatos dos trabalhadores, mediando uma verdadeira "conciliação de classes" pela superestrutura que é o Estado, conciliação esta que se dá pela interdependência entre as burguesias locais e estrangeiras, como afirmou Florestan Fernandes. Essa é uma das faces das estratégias de desenvolvimento econômico que a OCDE prega: a manutenção do capitalismo dependente organizado a partir de dentro dos países, membros ou colaboradores, como o Brasil.

Estiveram ainda presentes no grupo, na qualidade de observadores, o Banco Mundial, o Banco de Pagamentos Internacionais e o Fundo Monetário Internacional (FMI). Para a avaliação dos Princípios, o grupo de orientação convidou também como observadores ad hoc o Fórum para a Estabilidade Financeira (FEF), o Comité de Basileia de 


\title{
trabahonecessário
}

\author{
issn: 1808-799X
}

ano 8 - número 10 - 2010

\begin{abstract}
Supervisão Bancária e a Organização Internacional das Comissões de Valores (IOSCO). Durante a revisão dos Princípios, o grupo de orientação efectuou [sic.] extensas consultas e preparou, com a colaboração dos membros, um estudo sobre a evolução da situação nos Estados-Membros da OCDE (Survey of Developments in OECD Countries). Nas consultas participaram peritos provenientes de vários países, que estiveram presentes nas mesas redondas regionais sobre - governo das sociedades que a OCDE organiza na Rússia, Ásia, Sudeste da Europa, América Latina e Eurásia, com o apoio do Fórum Global para o Governo das Sociedades e outras instâncias internacionais, e em cooperação com o Banco Mundial e ainda outros países terceiros. Além disso, o grupo de orientação consultou um amplo leque de partes interessadas, como o sector [sic.] empresarial, investidores, associações profissionais a nível nacional e internacional, sindicatos, organizações da sociedade civil e organismos internacionais. (OCDE, 2004, p. 08) (grifos nossos)
\end{abstract}

A manutenção do capitalismo dependente, para a OCDE, é uma fonte de renda para a burguesia que a sustenta, atendendo às várias frações burguesas que a compõe: empresários do ensino, industriais, etc. Entendemos que o que está em jogo não é a melhoria das condições da educação para a classe trabalhadora, é a reprodução do capital dos países centrais, pertencentes à OCDE, na área social, em especial, saúde e educação (Chesnais, 2005).

Diante do exposto, é possível afirmar que o Brasil, de longa data, possui inúmeras dívidas com a OCDE e, como não é membro efetivo e não possui acordos que se tenham se tornado de conhecimento público antes de 2006 (quando o Brasil aderiu ao PISA), aparentemente os empréstimos ficam velados. Concluímos que, se o Brasil recebeu US\$376 milhões da OCDE e somente $7 \%$ era destinado à Educação, o restante do dinheiro pode ter sido destinado ao setor privado e /ou direcionado para determinadas áreas do setor público.

Entendemos que, por um lado, a OCDE reafirma o pacto burguês de mundialização do capital e, por outro, da educação (Melo, 2004). Esse pacto de "conversão da dívida pública em educação" (Lima, 2007), em termos políticosideológicos, vem incentivando a expansão do ensino fundamental sob a rédea da democracia restrita: amplia-se o acesso e limita-se a quantidade a ser 


\section{trabalhonecessário}

issn: 1808-799X

ano 8 - número 10 - 2010

investida, diversificando as formas de financiamento da educação. Como afirmou Neves (2002, p.164), as massas populares passam a ter a impressão de que estão "participando do banquete", ou seja, do acesso à educação sistematizada, pública e gratuita, com garantias de permanência e escolarização prolongada até a universidade; mas o cardápio é escolhido à sua revelia, ou seja, é organizado pela burguesia de forma a precarizar - com o corte orçamentário- e desqualificar o ensino público. O projeto neoliberal de educação buscou, desde os anos 90, no Brasil, alargar a base do sistema educacional brasileiro, precisamente o ensino fundamental, de modo a obrigar a classe trabalhadora, em geral, a uma terminalidade precoce da sua escolarização (idem, p.163-169). Hoje, esse alargamento vem-se dando no ensino superior por meio dos "escolões de terceiro grau" (idem), o que pode demonstrar que a educação básica alargada foi apenas uma fase inicial do processo:

Com respeito à ampliação do acesso ao ensino fundamental, também é bem-vinda a experiência do FUNDEF (um fundo para financiar despesas subnacionais com o ensino fundamental, baseado em um valor mínimo de despesa por estudante e transferências federais complementares), com o seu impacto sobre os índices de matrículas escolares. (OCDE, 2005, 51-57)

Concordamos com Lima (2002, p.54) quando afirma que a mercantilização da educação abriu espaço para duas palavras de manutenção da ordem social, econômica e cultural: expansão e democratização. O capital, a burguesia em geral, pelas mãos do Estado, utiliza essa estratégia de "contrarevolução preventiva" (Fernandes, 1981), mantendo a classe trabalhadora iludida com a ampliação do acesso ao ensino. Nas palavras de Neves (2005), isso é feito sem esta perceber que "o banquete servido à revelia pela burguesia" vem diminuindo a responsabilidade do Estado para com os outros níveis da educação, como é o caso do ensino superior e sua crescente expansão através da EaD. 


\title{
trabalhonecessário
}

\author{
issn: 1808-799X
}

ano 8 - número 10 - 2010

No tocante ao ensino superior, a "impressão de participação no banquete", a nosso ver, tem sido realizada pelas estratégias do governo Lula de utilizar programas como a Universidade Aberta do Brasil com a EaD, o PROUNI, REUNI e cursos de curta duração, fortalecendo o empresariamento na educação superior e, na contrapartida, sucateando ainda mais as universidades públicas com as avaliações do SINAES e da CAPES atreladas ao financiamento. Estamos conscientes de que as elites dominantes no Brasil têm interesse na mercantilização da educação superior, principalmente na área de ciência e tecnologia (C\&T) e de tecnologia da informação e comunicação (TICs). Acreditamos que estão buscando formas de operar o "colonialismo educacional" (Fernandes, 1975) com o subterfúgio de preparar as IES para a globalização dos sistemas educacionais na América Latina por meio da associação das universidades locais às globais, utilizando para isso a avaliação padronizada para obtenção do certificado de acreditação que viabiliza a diplomação compartilhada. Essa ação é, também, um fenômeno que esconde, na essência, a viabilização da mobilidade estudantil europeia para a América Latina. Acreditamos que o Acordo de Bolonha auxilia na recondução do excedente de mão de obra qualificada em nível superior, para que esta encontre emprego em outros países fora do circuito europeu.

Entendemos que o banquete, em termos de formação superior, vem sendo ofertado para a classe trabalhadora, numa estratégia de democratização da educação, por meio da EaD, impulsionada pela inovação tecnológica assim como a legalização de cursos de curta duração. O que vem sendo servido à classe trabalhadora, principalmente aos professores da educação básica, é uma formação aligeirada e fragmentada estimulada pela política neoliberal de profissionalização docente ou nas palavras de Shiroma (2003, p.61), pelo "eufenismo da profissionalização" organizado pela Práxis dos organismos internacionais. A formação docente via $\mathrm{EaD}$ e formação em serviço, que pode complementar a carga horária dos cursos de curta duração, seria mais uma estratégia de contrarrevolução preventiva por meio do aligeiramento da formação profissional disfarçada pela prerrogativa de "educação ao longo da 


\section{trabalhonecessário}

issn: 1808-799X

ano 8 - número 10 - 2010

vida" (BM, 2003) ou profissionalização na ótica do social-liberalismo, ampliando a massa de trabalhadores docentes mergulhados no estranhamento do trabalho e na alienação.

A expansão da educação básica e a democratização do ensino superior foram estratégias dos governos FHC e Lula da Silva para operar a conciliação de classes, assim, concluímos que a Contradição posta por uma e/ou por outra opera uma inclusão-excludente das massas e ao mesmo tempo, uma "exclusão-includente" (Kuenzer, 2002), na medida em que organizam-se meios de manter a dualidade estrutural do ensino. Para Kuenzer, as estratégias são as mais variadas possíveis, uma verdadeira "empurroterapia" (idem, p.93), uma visão de educação defendida pela esquerda, apropriada e distorcida pela direita a favor da manutenção da hegemonia, a ciclagem, a aceleração de fluxo, a progressão automática, as classes de aceleração (idem). A democratização das oportunidades educacionais pode-se dar independentemente das estratégias traçadas nos marcos da ordem, mas não é esse o tipo de educação que libertará a classe trabalhadora da exclusão cultural, social e econômica.

Florestan (1979) afirmou que as classes trabalhadoras precisam tomar consciência de que as burguesias periféricas tendem a se associar às burguesias centrais, repartindo desigualmente a mais-valia relativa, não sendo autônoma, não se organizando como classe em si e para si. Na busca de manter-se no poder, esta não anula, mas mantém este poder à custa de concessões políticas à classe trabalhadora. Por outro lado, recebe o apoio das burguesias centrais para se manter hegemônica e organizar a dominação a partir de dentro, minimizando qualquer manifestação da luta de classes. Seja pela organização de alianças com sindicatos e lideranças da classe, seja pela ascensão ao poder com um partido inicialmente marxista e que outrora se pretendeu revolucionário, como o PT. Hoje, transformado em partido de massa, intensifica suas vitórias eleitorais e faz uma acumulação gradativa de contrarreformas que mantêm a ordem social existente. 


\section{CONCLUSÕES SOBRE A RELAÇÃO DE DEPENDÊNCIA} MANIFESTADA PELO FENÔMENO DA MERCANTILIZAÇÃO DA EDUCAÇÃO

A conversão da dívida, pautada no projeto internacional de "Educação para Todos", encabeçado por organismos internacionais desde 1990, é uma moeda de troca para promover a complementação dos tipos de contrarreformas que os organismos internacionais defendem. Está explícita a busca do capital, por intermédio dos organismos, no sentido de beneficiar os empresários do ensino e mediar empréstimos às empresas da área da educação, principalmente aos países latinos, com juros altíssimos. As regras impostas pelo BM, FMl e a OCDE auxiliam a mediação de acordos obrigando os países membros a flexibilizar e a adaptar a legislação nacional às da OCDE por intermédio de acordos supranacionais. Os países colaboradores também podem aderir, sendo que, uma das prerrogativas, é de que o Estado venha a assumir parte da dívida no caso de falência das empresas nacionais que realizaram empréstimos, sendo isso um meio de sugar os fundos públicos pela parceria público-não estatal ou público-privada. No caso brasileiro, essa brecha já foi estabelecida com a criação do MARE (BRESSER PEREIRA, 1997). Então, por que o Brasil não se torna membro efetivo da OCDE? Dentre os motivos, o principal é o de que, ao invés de receber ajuda financeira, terá que emprestar dinheiro e abrir todos os setores para a livre interferência da OCDE, sendo, para o Governo Lula, mais interessante mercantilizar a educação superior com a justificativa de "perdão de parte da dívida pública" por investimento em educação básica.

O tema da mercantilização da educação foi abordado tendo por base uma análise da política econômica do Tratado de Livre Comércio, organizado a partir do Acordo Geral sobre o Comércio de Serviços da OMC, o qual buscou, por meio da ALCA, garantir que os países Latinoamericanos se adaptassem, juridicamente, às políticas macroeconômicas impostas pelos Organismos Internacionais, prioritariamente na esfera da educação superior, na qual a 


\section{trabahonecessário}

issn: $1808-799 \mathrm{X}$

ano 8 - número 10 - 2010

modalidade de educação à distância veio-se expandindo como expressão desta Práxis. Para Lima (2007, p.126-187), o padrão dependente de educação superior no Brasil vem sendo reorganizado sob a forma de uma "reforma universitária consentida" (Fernandes, 1979) e conduzida pelo capital. Parafraseando a autora para especificar nossa hipótese, a OCDE e os organismos internacionais buscam, na América Latina, reeditar a "transplantação de conhecimentos e de modelos de universidades européias" (idem), reorganizando o que Florestan Fernandes denominou como "colonialismo educacional". Tal intento, posto claramente com o Acordo de Bolonha ${ }^{3}$, também busca ampliar a inserção do capital estrangeiro na área dos chamados serviços educacionais, além de procurar (con)formar um novo homem/trabalhador adequado à atual fase do capitalismo.

Para Leher (2005), essa mercantilização da educação no Brasil abriu o mercado para o empresariado em geral, principalmente após a criação da Universidade Aberta do Brasil. O MEC, segundo o autor, na época da escrita do referido texto, "vê com bons olhos a internacionalização das instituições de ensino superior que deveria ser vetada pela lei para não agravar a heteronomia cultural" (2005, p.1). A expressão "bons olhos" refere-se à alegação de que o investimento estrangeiro em educação, certamente, seria aprovado para além de $30 \%$. Nos limites da pesquisa para este trabalho, foi constatado que a OCDE mantém parceria com o INEP/MEC que procura ampliar tal campo de exploração para o capital estrangeiro, prioritariamente na área de formação de professores, na qual vem atuando com força, sendo que, nos últimos anos, fez vultosos empréstimos ao Brasil para a "melhoria" da qualidade na educação, especificamente do ensino fundamental.

Segundo Olinda Evangelista (2007), as políticas internacionais de formação docente são incorporadas pelo Estado brasileiro como instrumentos úteis para obtenção do controle sobre a maior e potencialmente a mais subversiva categoria do funcionalismo público: os professores. Além da reprodução político-ideológica, via formação docente em nível superior, os organismos internacionais em parceria com os Estados nacionais, procuram 


\title{
trabahonecessário
}

\author{
issn: $1808-799 \mathrm{X}$
}

ano 8 - número 10 - 2010

abrir mercado na área de bens e serviços educacionais para mediar a reprodução do capital em ampla escala, de modo transfronteiriço, beneficiando a burguesia como um todo. A autora destacou três grandes projetos internacionais em andamento na América Latina, concebidos, teoricamente, utilizando conceitos e ideias comuns como meio de criar consenso e convencer as massas. São eles o Proyecto Regional de Educación para America Latina y Caribe (PREALC), patrocinado pela Unesco desde 2002; o Plan Cooperación (PC), patrocinado pela Organización de Estados Iberoamericanos para la Educación, la Ciência y la Cultura (OEI), este, apoiado/assistido pela OCDE desde 2000; e o Proyecto Hemisférico em Educación (PHE), patrocinado pela Organização dos Estados Americanos (OEA) desde 1994, no qual atuam como patrocinadores a Unesco, a Unicef, o Convênio Andrés Bello, o BIRD, o BM e a OEI (Torres, 2004, apud Evangelista, 2007, p.2).

Tal processo visa à organização de estratégias de convencimento das massas também vem-se desdobrando na formação docente, a qual, segundo a ótica dos organismos internacionais, deve ser dar em nível superior, sem no, entanto, ser uma formação em universidades. Entendemos que esta proposta reforça a ideia de que esta formação deve ser organizada por meio da formação contínua (leia-se formação em serviço) utilizando a EaD, prioritariamente, como estratégias de pseudodemocratização do ensino superior. Para a referida autora, os organismos multilaterais criaram uma comunhão conceitual básica, que deve ser veiculada pela educação nos países latinos, operando, assim, alguns conceitos particulares como "desenvolvimento humano", sugerindo que, em determinados lugares do planeta, alguns grupos são menos humanos e não habituados às regras, ou seja, a população pobre; por isso a ideia de desenvolvimento humano possui, assim, um componente econômico e outro cultural (Shiroma \& Evangelista, 2005, apud Evangelista, 2007, p.2).

Outro conceito básico, na ótica da referida autora, é o de formação contínua ou "educação ao longo da vida", o qual, segundo textos produzidos por organismos internacionais, pressupõe não ser suficiente a escolarização 


\section{trabalhonecessário}

issn: $1808-799 \mathrm{X}$

ano 8 - número 10 - 2010

inicial para a para o desenvolvimento pleno dos seres humanos; mas, na essência, a ideia é moldar a mentalidade do trabalhador a cada época conforme a evolução dos meios de produção para adaptá-lo às demandas do capital. Para Evangelista (2007), somado a esses conceitos, a "pedra de toque" que dá a explicação para os males que atingem o universo do trabalho seria a iminência e a primazia das tecnologias da informação e comunicação como mediadora da inclusão e manutenção do indivíduo no mundo do trabalho. Logo, educar ao longo da vida demandaria fazer, primeiramente, do professor um trabalhador capaz de manusear e transmitir conhecimentos da área de TICs aos futuros trabalhadores. Tal processo operacionaliza a compra de pacotes tecnológicos pelos países periféricos e a difusão da ideologia burguesa, isto é, as determinações econômicas, culturais e políticas. Daí a ênfase na formação por competências adotada nos textos dos organismos como a OCDE e do próprio Governo, como é o caso do Programa Toda Criança Aprendendo, considerado, por outra autora, Freitas (2003), o escopo da política de formação continuada e da certificação de professores, o que culminou na criação das matrizes de competência e da Rede Nacional de Centros de Pesquisa e Desenvolvimento da Educação. Essas matrizes foram projetadas para se constituírem enquanto referência não apenas para os processos de certificação de professores, mas também de acreditação e de autorização das instituições formadoras (idem, 2003, p.1095).

Segundo Freitas (2003), atestando as ações do MEC, via Secretaria de Educação Infantil e Fundamental (SEIF), a proposta era de que a partir de 2000 a certificação fosse provisória, como sugere a OCDE, podendo ser renovada caso o professor se submetida e for aprovado em $175 \mathrm{~h}$ de educação continuada e obtendo um certificado de mestrado profissionalizante, ou seja, sem defesa de tese, no prazo máximo de dois anos a contar da data da sua formatura. Para Freitas (2003, p.1110), "a proposta enfatiza a utilização das novas tecnologias educacionais e a informática como caminhos para a superação dos problemas da formação de professores". O autor apontou que a formação de professores na modalidade à distância havia-se transformado em 


\title{
trabalhonecessário
}

\author{
issn: $1808-799 \mathrm{X}$
}

ano 8 - número 10 - 2010

carro-chefe das políticas do governo Lula, como estratégia de firmar "pactos pela educação, pela aprendizagem, pelo letramento, pela alfabetização" (idem), pactos estes realizados entre as diversas frações burguesas, diluídas as fronteiras nacionais e internacionais na busca de garantir aos empresários do ensino espaço para reprodução do capital.

Concordamos com Shiroma, Moraes e Evangelista (2003), que, para garantir a área da formação docente sob o controle do capital, os organismos internacionais estabeleceram estratégias coercitivas sob a forma de financiamento da educação (Lima, 2007), Práxis que envolveu empréstimos financeiros, atrelando os resultados dos investimentos em educação a novos empréstimos ou perdão de parte da dívida pública, trocando-a por investimento em educação. Tais autoras afirmaram que, na verdade, há um conceito e uma prática fundamental, ao mesmo tempo em que medeia a coerção da classe trabalhadora, da categoria docente, prática esta que, pelas mãos do Estado, chega até as salas de aula: a avaliação. Segundo Evangelista (2003, p.2), a“OEA afirma: 'a educação tem que estar em consonância com o mercado'. A Unesco agrega:'o sujeito tem que ser empreendedor'”. A ideia de ser um cidadão empreendedor está ligada ao ideário de formação de pessoas preparadas para lidar com um mundo sem emprego e esta tarefa recai, certamente, sobre os ombros do professor. Para Evangelista (2007, p.2) esse controle sob os valores que nortearão o trabalho docente é realizado pela política de Avaliação, na qual a gestão da educação se desdobra não só no campo da formação, mas no da administração do sistema e no que a autora define como "projeto capitalista de educação" (idem), ou projeto burguês de sociedade, que garanta a reprodução do capital via manutenção da hegemonia com a subordinação da classe trabalhadora.

A problemática da mercantilização da educação a partir da internacionalização do ensino superior com o Acordo de Bolonha no fim dos anos de 1990 configurou-se como processo de inserção subordinada dos países periféricos (Siqueira, 2005), na medida em que a produção do conhecimento se concentrou nos países centrais, e aos periféricos foi dada a 


\section{trabalhonecessário}

issn: $1808-799 \mathrm{X}$

ano 8 - número 10 - 2010

tarefa de fazer das suas universidades e escolas centros de reprodução do conhecimento com a importação tanto de modelos educacionais, quanto da ciência e da tecnologia. Entendemos ser, mediante avaliação como estratégia de coerção e consenso imposta pelos organismos internacionais como forma de monitorar a educação, que se formará a mão de obra trabalhadora em diversos níveis, que a construção ideológica da profissionalização docente, nos parâmetros dos organismos internacionais e dos empresários da educação (Rodrigues, 2007) vem transformando os centros de ensino em aparelhos privados de hegemonia, e o professor, é num mediador do processo de convencimento das massas para a obtenção do consenso. Nas palavras de Florestan Fernandes (1981), a avaliação seria a estratégia de contrarrevolução preventiva e prolongada, atrelando a produção da escola ao financiamento da educação. A ideia consiste em forjar mediações para capturar a subjetividade da classe trabalhadora, materializando o convencimento para obtenção do consenso.

Enfim, estão sendo criadas instituições de Avaliação Educacional, onde o trabalho docente vem sendo o "Judas" que trai o ensino de "qualidade" propagado pelos organismos internacionais. Um exemplo é o Programa de Avaliação Diagnóstica dos Alunos da Rede Municipal de Niterói, projetado em 2009 para ser implantado em 2010. A Fundação Municipal de Educação de Niterói contatou a consultoria do Centro de Políticas Públicas de Avaliação da Educação da Universidade Federal de Juiz de Fora (CAED/UFJF) para organizar as matrizes dos testes padronizados, baseados na verificação de aquisição de competências e as avaliações externas, a serem realizadas por provas padronizadas como pré-teste para preparação das avaliações oriundas do Governo.

Outras instituições contratadas foram o Centro de Alfabetização, Leitura e Escrita da Universidade Federal de Minas Gerais (CEALE/UFMG) e a Fundação Darcy Ribeiro, que, junto com pesquisadores como Ana Canen, da Universidade Federal do Rio de Janeiro, vem organizando os referenciais curriculares da rede com respaldo discursivo do "multiculturalismo", ou seja, 


\section{trabalhonecessário}

issn: $1808-799 \mathrm{X}$

ano 8 - número 10 - 2010

com o discurso da "inclusão social". Para além, tais órgãos vem dando formação continuada aos docentes e gestores da rede. Atualmente, o CEALE, além de fornecer formação continuada, é o responsável, junto ao MEC, pela organização da Prova Brasil. Logo, vê-se, claramente, a participação/cooptação de setores das universidades públicas para um projeto burguês de educação (Melo, 2004) que, antes de tudo, rende-lhes financiamento público. Concluímos que estas políticas estão sendo orientadas pelo MEC/INEP sob a interferência da OCDE e outros organismos. Sendo assim encontramos orientações deste organismo implantado no chão das redes de ensino. Então, na lógica da conversão da dívida pública em educação básica a ordem é: democratizar na aparência para mercantilizar na essência.

\section{BIBLIOGRAFIA:}

BANCO MUNDIAL. Aprendizaje Permanente em la Economia Global del Conocimiento. Desafios para los países em desarrolo. México, D.F: Alafaomega Colombiana S.A., 2003.

O ensino superior: as lições derivadas da experiência. 1994.

BRESSER-PEREIRA, Luiz Carlos. A Reforma do Estado dos anos 90: Lógica e Mecanismos de Controle. MARE. Brasília, DF, 1997.

BOITO JÚNIOR, Armando. Política neoliberal e sindicalismo no Brasil. São Paulo: Xamã, 1999

CALIENDO, Paulo. Estabelecimentos Permanentes de Direito Tributário e Internacional. São Paulo: Editora Revista dos Tribunais, 2005.

CHESNAIS, François. Apresentação à edição brasileira. In. CHESNAIS, François (Org.). Tradução de MARQUES, Rosa Maria. NACATANI, Paulo. A finança mundializada: raízes sociais e políticas, configuração, conseqüências. São Paulo: Boitempo, 2005a, p.17-32.

DRUCKER, Peter. Sociedade pós-capitalista. São Paulo: Pioneira, 1993.

EVANGELISTA, Olinda. Formação docente no Brasil e interesses internacionais. Santa Catarina, 2007. (Disponível em www.gepeto.ced.ufsc.br)

FERNANDES, FLORESTAN. Brasil: em compasso de espera. Hucitec, 1979. 


\section{trabalhonecessário}

issn: $1808-799 \mathrm{X}$

ano 8 - número 10 - 2010

Capitalismo dependente e classes sociais na América Latina. $3^{\mathrm{a}}$ ed. Rio de Janeiro: Zahar Editores, 1981

FIDALGO, Fernando Selmar. Gerência da qualidade total na educação: a privatização do público. In. FIDALGO, Fernando Selmar. MACHADO, Lucília Regina de Souza. (Orgs.) Controle da qualidade total: uma nova pedagogia do capital. Belo Horizonte: Movimento Cultura Marxista. 1994, p.65-78.

FIORI, José Luiz. Globalização, hegemonia e império. In. TAVARES, M.C. e FIORI, J.L. (Eds.) Poder e dinheiro. Uma economia política da globalização. Petrópolis, RJ: Vozes, 1998, p. 87-144.

FREITAS, Helena Costa Lopes. Certificação docente e a formação do educador: regulação e desprofissionalização. Educação \& Sociedade: Campinas, vol. 24, nํ5, 2003, p. 1095-1124.

INEP. Pesquisa Internacional sobre ensino e aprendizagem (TALIS). Ações Internacionais. $2008 . \quad$ (Disponível em http://www.inep.gov.br/internacional/novo/TALIS/oquee.htm 2009 pesquisa $\underline{\text { talis) }}$

Disponível

Relatório das ações internacionais do INEP 2006. Ano 2007. www inep gov.br/download/internaciona/Relatório Aç̃os Internacionais em pdf>

KOSIK, Karel. A dialética do concreto. Rio de Janeiro: Paz e Terra, 1976.

KUENZER, Acácia Zeneida. Desafios teóricos-metodológicos da relação trabalho-educação e o papel da escola. In FRIGOTTO, Gaudêncio. Educação e crise do trabalho. Perspectivas de final de século. Petrópolis: Vozes, 1998, p.55-75.

Exclusão includente e inclusão excludente. A nova forma de dualidade estrutural que objetiva as novas relações entre trabalho e educação. In. LOMBARDI, José Claudinei. SAVIANI, Demerval. SANFELICE, José Luís (Orgs.) Capitalismo, Trabalho e Educação. Campinas, São Paulo: Autores Associados, HISTERDBR, 2002, p.77-95.

As relações entre trabalho e educação no regime de acumulação flexível. Apontamentos para discutir categorias e políticas. Mimeo. 2007, 21p.

LENIN, V.I. O Estado e a Revolução: o que ensina o marxismo sobre o Estado e o papel do proletariado na revolução. $1^{\underline{a}}$ ed. São Paulo: Expressão Popular, 2007.

LEHER, Roberto. Feições da mercantilização da educação e neocolonialismo. Outro Brasil, 2005 (Disponível em www.outrobrasil.net ) 


\section{trabalhonecessário}

issn: $1808-799 \mathrm{X}$

ano 8 - número 10 - 2010

LIMA, Katia. Contra-reforma na educação superior: de FHC a Lula. São Paulo: Xamã, 2007

Organismos Internacionais: o capital em busca de novos campos de exploração. In. NEVES, Lúcia Maria Wanderley. O empresariamento da educação: novos contornos do ensino superior no Brasil dos anos 1990. São Paulo: Xamã, 2002.

MARX, Karl. O Capital. Livro I. Capítulo VI (inédito). São Paulo: Editora e livraria Ciências Humanas LTDA, 1984.

MAUÉS, Olgaíses Cabral. Reformas Internacionais da educação e formação de professores. Cadernos de Pesquisa, n.118, p.89-117, março, 2003.

MELLO, Luiz. Apresentação do relatório econômico do Brasil 2005. OCDE (Disponível em www.oecd/brazil)

MELO, Adriana Sales. A mundialização da educação. Consolidação do projeto neoliberal na América Latina, Brasil e Venezuela. Maceió: EDUFAL, 2004.

NEVES, Lúcia Maria Wanderley (Org). O empresariamento da Educação: novos contornos do ensino superior no Brasil dos anos 1990. São Paulo: Xamã, 2002.

A nova pedagogia da hegemonia. Estratégias do capital para educar para o consenso. São Paulo: Xamã, 2005.

A reforma da educação superior e a formação do novo intelectual urbano. In. SIQUEIRA, Ângela C. de. NEVES, Lúcia Maria W. (Orgs.) Educação Superior: uma reforma em processo. São Paulo: Xamã. 2006, p.81106.

MORAES, Maria Célia M. de. Iluminismo às avessas. Produção do conhecimento e políticas de formação docente. Rio de Janeiro: DP\&A, 2003.

OCDE. Os princípios da OCDE sobre o governo das sociedades. OECD Principles of Corporate Governance, 2004.

Metodologia para avaliação de sistemas nacionais de aquisição de bens de serviços. Versão 4, 17 de julho de 2006a. (Disponível em $<$ www.oecd.org/brasil> último acesso em 12/04/2008)

Estudos econômicos da OCDE Brazil 2005. Rio de Janeiro: Editora FGV, 2006b, 244p.

OLIVEIRA, Francisco. Os direitos do antivalor. A economia da política da hegemonia imperfeita. Petrópolis, RJ: Vozes, 1998, 9-76. 


\section{trabalhonecessário}

issn: $1808-799 \mathrm{X}$

ano 8 - número 10 - 2010

P. MELO, Marcelo. FALEIROS, lalê. Reforma da aparelhagem estatal: novas estratégias de legitimação social. In. NEVES, Lúcia Maria Wanderley (Org). A nova pedagogia da hegemonia. Estratégias do capital para educar para 0 consenso. São Paulo: Xamã, 2005, p. 175-192.

RAMOS, Marise. A pedagogia das competências. Autonomia ou adaptação? 2a ed. São Paulo: Cortez, 2002.

RODRIGUES, José. Os empresários e a educação superior. Campinas: Autores Associados, 2007.

SIQUEIRA, Ângela C. de (2001). Organismos internacionais: educação em uma política de educação soberana? Porto alegre, RS: Trabalho apresentado do Fórum Mundial de educação, Sessão de Debate Especial "Organismos Internacionais, tratados de livre comércio e reformas educacionais: a educação em uma política de integração soberana". (Disponível on-line no site www.forummundialeducacao.org.br)

A regulamentação do enfoque comercial no setor educacional via OMC/GATS. Revista Brasileira de Educação. RJ: ANPED; SP: Autores Associados, vol.26, 2004.

SIQUEIRA. Pós-graduação em educação e a internacionalização do conhecimento: direito ou serviço? Belo Horizonte, MG: UFMG/PUC-MG, ANPEd, 2005.

SIQUEIRA, Ângela C. de. NEVES, Lúcia Maria W. (Orgs.) Educação superior: uma reforma em processo. São Paulo: Xamã. 2006

SILVA JÚNIOR, João dos Reis. Reformas do Estado e da educação: no Brasil de FHC. São Paulo: Xamã, 2002.

SOUZA JÚNIOR, Hormindo Pereira de. Forma e conteúdo na construção ideológica do discurso de qualidade. In. FIDALGO, Fernando Selmar. MACHADO, Lucília Regina de Souza. (Orgs.) Controle da qualidade total: uma nova pedagogia do capital. Belo Horizonte: Movimento Cultura Marxista. 1994, p.57-62.

SHIROMA, Eneida Oto. CAMPOS, Roselane Fátima. Qualificação e reestruturação produtiva. Um balanço das pesquisas em educação. Educação \& Sociedade, ano XVIII, № 61, dezembro/1997, p.13-35.

Implicações da Política de profissionalização sobre a gestão e o trabalho docente. Revista Trabalho \& Educação; vol.13, n 2, agosto /dezembro, 2004, p.113-125.

O eufenismo da profissionalização. In. MORAES, Maria Célia Marcondes de. (Org.) lluminismo às avessas: produção de conhecimento e políticas de formação docente. Rio de Janeiro: DP\&A. 2003, p. 61-98. 


\section{trabalhonecessário}

issn: $1808-799 \mathrm{X}$

ano 8 - número 10 - 2010

MORAES, Maria Célia M. de. EVANGELISTA, Olinda. Política educacional: o que você precisa saber sobre. 3르 ed. Rio de Janeiro: DP\&A, 2004.

R. Souza, Thaís. (Con)formando Professores Eficazes: a relação política entre - Brasil e a Organização para Cooperação e Desenvolvimento Econômico (OCDE)/ Thaís Rabello de Souza. Niterói: UFF. Dissertação (Mestrado em Educação). 2009.

TOMMASI, L. WARDE. J. e HADDAD. S. (Orgs.). O Banco Mundial e as políticas educacionais. 3ª ed. São Paulo: Cortez, 2000, p.125-193.

TORRES, Rosa Maria. Melhorar a qualidade da educação básica? As estratégias do Banco Mundial. In: DE TOMMASI, L.WARDE.J. e HADDAD. S. (Orgs.). O Banco Mundial e as políticas educacionais. 3a ed. São Paulo: Cortez, 2000, p.125-193.

UNESCO. Docentes para lãs escuelas Del mañana. análisis de los indicadores educativos mundiales. OCDE, 2001.

Mundialização e reforma da educação: o que os planejadores devem saber. 2002.

Il Reunião do comitê social de conversão da dívida pública por

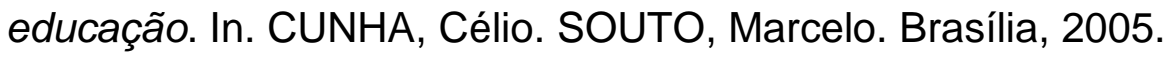

VÁZQUEZ, Adolfo S. O que é Práxis: filosofia da Práxis. Rio de Janeiro: Paz e Terra, 1997, p.185-208.

\footnotetext{
Mestre em Educação pela Universidade Federal Fluminense; membro do Núcleo de Educação Internacional Comparada (NEIC).

Segundo Lima (2007), Giddens é um "sociólogo britânico, reitor da London School of Economics (importante centro formulador do pensamento liberal europeu), assessor direto de Tony Blair e um dos mais importantes articuladores políticos do trabalhismo inglês, sendo organizador da Cúpula Mundial da Governança Progressista." (idem, p.58)

$\mathrm{Na}$ área da Educação Superior, a OCDE criou o Programa de Gerenciamento de Educação Superior (Programme on Institutional Management on Higher Education- IMHE), dando continuidade à política de promoção dos acordos realizados no Processo de Bolonha tocante ao Brasil, afirmamos que dele participam a Universidade Estadual do Campinas (UNICAMP) e a Universidade Federal do Paraná (UFPR). Esta última, em 2006 realizou um trabalho conjunto com a OCDE sobre avaliação do ensino nas universidades do Centro-Oeste paranaense.
} 